\title{
Crystal structure of correianevesite from the Emmons pegmatite, Uncle Tom Mountain, Greenwood, Oxford County, Maine
}

\author{
Manuscrit reçu le1 ${ }^{\mathrm{er}}$ novembre 2020 et accepté le 15 janvier 2021
}

\author{
Pietro Vignola ${ }^{1}$, Francesco Demartin ${ }^{2}$, Italo CAMPOSTRINI ${ }^{2}$, Alexander U. FALSTER ${ }^{3}$, \\ William B. SimMONS ${ }^{3}$ and Raymond A. SPRAGUE ${ }^{4}$
}

${ }^{1}$ Consiglio Nazionale delle Ricerche, Istituto di Geologia Ambientale e Geoingegneria, via Mario Bianco 9, 20131 Milano, Italia.

${ }^{2}$ Università degli Studi di Milano, Dipartimento di Chimica, via Golgi 19, 20133 Milano, Italia.

${ }^{3}$ Maine Gem et Mineral Museum, PO Box 500, 99 Main St, Bethel, Maine 04217.

${ }^{4} 33$ Roger Street, Lewiston, 042040 Maine. (deceased April 16 ${ }^{\text {th }} 2019$ ).

\begin{abstract}
Correianevesite, $\mathrm{Fe}^{2+} \mathrm{Mn}^{2+}{ }_{2}\left(\mathrm{PO}_{4}\right)_{2} \cdot 3 \mathrm{H}_{2} \mathrm{O}$, is an uncommon secondary phosphate in granitic pegmatites. Described for the first time from the Cigana pegmatite (Conselheiro Pena, Brazil), it was subsequently reported only at the Berry-Havey pegmatite (Androscoggin County, Maine, U.S.A.). A single crystal from a new occurrence at the Emmons pegmatite, Oxford Co., Maine, gave the following unit cell unit cell parameters: $a=9.4872(19), b=10.121(2), c=8.7023(17)$ $(\AA), V$ 835.6(3) $\left(\AA^{3}\right)$. The structure was anisotropically refined in the orthorhombic system, space group Pbna down to a $\mathrm{R}=1.6 \%$ and the hydrogen-bond pattern could be determined. Microprobe chemical analysis, and bond valence calculation show the expected values for all the atomic sites and confirmed the valence of all ions in the structure.
\end{abstract}

Keywords: correianevesite, pegmatite phosphate, single-crystal X-ray diffraction, crystal structure, Emmons pegmatite

\section{Introduction}

Correianevesite, $\mathrm{Fe}^{2+} \mathrm{Mn}^{2+}{ }_{2}\left(\mathrm{PO}_{4}\right)_{2} \cdot 3 \mathrm{H}_{2} \mathrm{O}$, was described for the first time at the Cigana granitic pegmatite (Conselheiro Pena, Minas Gerais, Brazil) by Chukanov et al. (2014). This species was described in the orthorhombic system, space group Pbna with $a=9.48871(16)$, $b=10.11494(17), c=8.70624(16)(\AA), V$ 835.61(3) $\left(\AA^{3}\right)$ and $\mathrm{Z}=4$. A second occurrence of correianevesite is the Berry-Havey mine (Poland, Androscoggin County, Maine, U.S.A) as described in King and Foord (2000). The mineral belongs to the phosphoferrite group, phosphoferrite-reddingite series. As pointed out in Chukanov et al. (2014) the structure of correianevesite conforms closely to the structural model of the phosphoferrite group minerals. This structure type was described by Moore et al. (1980) in the same orthorhombic system, space group Pbna. The structure of phosphoferrite group minerals, that can be represented by the structural formula $\mathrm{M}(1) \mathrm{M}(2)_{2}\left(\mathrm{PO}_{4}\right)_{2} \cdot 3 \mathrm{H}_{2} \mathrm{O}$, comprises two octahedral sites, $\mathrm{M}(1)$ and $\mathrm{M}(2)$ 
accommodating mainly $\mathrm{Fe}$ and $\mathrm{Mn}$, and one tetrahedral site accommodating $\mathrm{P}$. The framework is constituted by sheets of corner- and edge-sharing octahedra oriented parallel to $\{100\}$. The octahedra sheets are linked by corner-sharing tetrahedra. The result is a rigid framework of octahedra and tetrahedra.

We report here new data on correianevesite from a new occurrence at the Emmons pegmatite, Oxford Co., Maine, obtained using electron microprobe and single-crystal X-ray diffraction.

\section{Sample description and mineralogy}

The specimen used for this study was found by one of the authors (A.U.F) during a field trip at the Emmons pegmatite, Uncle Tom Mountain, Greenwood, Oxford County, Maine. The specimen, stored in the collection of one of the authors (P.V., catalogue n 4644) consists of rough bipyramids, partly etched or corroded masses with a dark brown color. The specimen was collected from an altered mass of lithiophilite in close association with radial aggregates of hexagonal elongated prisms of fluorapatite, stewartite and laueite crystals.

The Emmons pegmatite (Fig. 1 inset) occurs in the Oxford pegmatite field in Oxford Co., Maine and is an example of a highly evolved boron-beryllium-lithium-cesium-tantalum enriched pegmatite (Falster et al., 2019) showing a well evident LCT signature (Černý and Ercit, 2005). The complexly zoned pegmatite is exposed over an area of $120 \mathrm{~m} \times 18 \mathrm{~m}$ (Fig. 1).

The wall zone in the hanging wall of the pegmatite is clearly recognizable by its comb-texture schorl with schorl crystals oriented approximately perpendicular to the contact. The wall zone in the footwall of the pegmatite does not have comb-texture schorl but has two well-defined layers, one with garnet and one schorl. The wall zone consists of quartz, microcline, albite, muscovite, schorl, garnet group species (almandine-rich). The pegmatite likely did not change much from its original orientation. This is confirmed by the position of 'snow on the roof' in some miarolitic cavities that confirm that no major change in orientation has occurred since the pegmatite's formation.

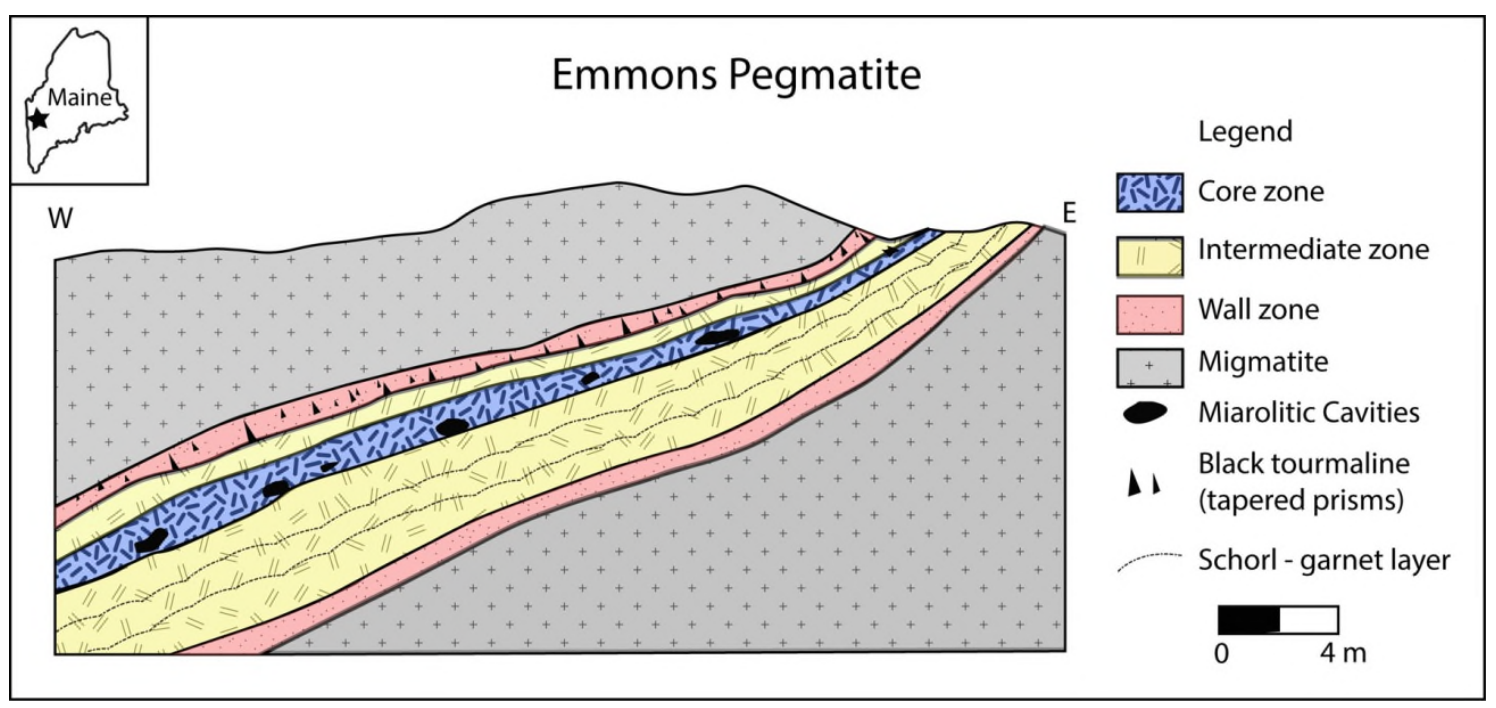

Figure 1: Cross section of the Emmons pegmatite 
The intermediate zone, which is the next zone inward, consists of feldspars and quartz with some muscovite; additional minerals such as zircon, uraninite, fluorapatite, columbite group species, mainly columbite-(Fe), are more abundant. In small miarolitic cavities and open fractures near pinkish, metasomatized microcline, small quartz crystals, albite crystals and cleavelandite rosettes as well as muscovite rosettes and coatings of crystals are present. Rarely, fluorapatite and bertrandite may also be found. The core margin is outlined by a layer of ball muscovite with the convex portion pointing to the core. In areas where the core is bulging, the core margin ball muscovite may exhibit very complex twisting. Many exotic species may be found in the core margin. "Ball muscovite" is typically present and associated with the evolved mineralogy. Primary phosphate masses of lithiophilite-triphylite and montebrasite and their secondary minerals are found here. Pollucite, and alkali-rich beryl can occur here. Miarolitic cavities occur in the core margin and core zone and may contain crystals of quartz (colorless, milky, smoky quartz is rare), muscovite, albite, microcline, beryl (usually etched), cassiterite and $\mathrm{Nb}$-Ta species. Rare lepidolite can be found. The core zone is quartz-rich and contains extensive but discontinuous masses of quartz. Along the core margin boundary are pods of pollucite and phosphates (lithiophilite-triphylite and montebrasite). Spodumene is also present but is frequently altered to smectitic clay. Replacement units are widespread in the core and core margin area of the pegmatite. The replacement units may be rich in small cavities i.e. "miaroles" that are commonly interlinked. A large mass is currently exposed at the lowest outcrop exposure level, but a smaller one can be seen on the uppermost quarry wall. In these cavities a wealth of microminerals ( $1 \mathrm{~mm}$ or less) can be found. Examples include quartz, muscovite, cassiterite, fluorapatite, bertrandite, perhamite, zircon, columbite-tantalite, hydroxylherderite, tantalowodginite (Hanson et al., 2018), and many others. In the core margin and core zone, replacement of primary phosphates by secondary phosphates is widespread. Schorl and almandine partially or completely replaced by muscovite occur frequently.

Alteration of the primary phosphate pods (lithiophilite, triphylite, montebrasite) produces a wealth of mineral species (Moore, 1973; Simmons et al., 2003). In most cases, montebrasite and lithiophilite/triphylite pods are closely associated with montebrasite, which adds to the mineral complexity because aluminum from montebrasite can give rise to Al-bearing phosphates such as childrenite-eosphorite, brazilianite and others. The actual alteration products are generally present only in small amounts and they tend to be near the upper parts of the phosphate pods. In the lithiophilite/triphylite pods, mineralogically distinct areas exist where particular mineral associations are located, for example strunzite, laueite, stewartite, fairfieldite or, childrenite-eosphorite, brazilianite. In the-high manganese pods, hureaulite is widespread and is sometimes the only secondary phosphate. Rhodochrosite is commonly associated with lithiophilite. In some cases, a more complex mineral association has formed, recognizable by the presence of mitridatite. The presence of beryl may contribute beryllium to the alteration assemblage producing hydroxylherderite, väyrynenite, or moraesite. An example of a recently found primary phosphate pod that appeared initially as two distinct masses and was found to be a single pod. The upper part of the pod is richer in Fe and the lower portion is richer in Mn. In addition, rhodochrosite appears in two chemically and texturally distinct types: elongated crystals within massive lithiophilite and as masses of porous rhodochrosite with the voids commonly rich in phosphate species. 
Typically, miarolitic cavities in the core zone and along the core margin are albite and muscovite-rich, with variable amounts of quartz and microcline. Accessory species can include fluorapatite, beryl, bertrandite, hydroxylherderite, $\mathrm{Nb}$-Ta oxide species, and rare etched spodumene.

\section{Analytical Methods}

Quantitative electron-microprobe analyses were performed on a polished section using a JEOL JXA-8200 microprobe in wavelength-dispersive mode at the Earth Sciences Department of the Università degli Studi di Milano. The system was operated using an accelerating voltage of 15 $\mathrm{kV}$, a beam current of $5 \mathrm{nA}$ with a beam diameter of $5 \mu \mathrm{m}$, and a counting time of $30 \mathrm{~s}$ on the peaks and $10 \mathrm{~s}$ on the backgrounds. The following minerals were used as standards: graftonite KF-16 (Fransolet, 1975) for $\mathrm{P}, \mathrm{Fe}, \mathrm{Mn}$ and $\mathrm{Ca}$, grossular for $\mathrm{Si}$ and $\mathrm{Al}, \mathrm{K}$-feldspar for $\mathrm{K}$, forsterite for $\mathrm{Mg}$, omphacite for $\mathrm{Na}$, hornblende $\mathrm{h}-123$ for $\mathrm{F}$, realgar for $\mathrm{As}$, rhodonite for $\mathrm{Zn}$, celestine for $\mathrm{Sr}$, barite for $\mathrm{Ba}$ and scapolite for $\mathrm{Cl}$. The elements $\mathrm{Si}, \mathrm{Al}, \mathrm{K}, \mathrm{Na}, \mathrm{F}, \mathrm{Ba}$, and $\mathrm{Cl}$ were below detection limits in all analyzed points. The raw data were corrected for matrix effects using the protocol implemented in the JEOL suite of programs. Table 1 shows the chemical composition of the analyzed specimen with the empirical formula calculated considering $2 \mathrm{P}$ atoms per formula unit (apfu) as indicated by the IMA-CNMNC.

Table 1: Electron microprobe analysis of correianevesite.

\begin{tabular}{|c|c|c|c|c|c|}
\hline & \multicolumn{2}{|c|}{ average of 10 points } & & & \multirow[b]{2}{*}{ a pfu } \\
\hline & $\mathrm{wt} \%$ & $S D$ & & & \\
\hline $\mathrm{P}_{2} \mathrm{O}_{5}$ & 34.56 & 0.39 & \multirow[t]{2}{*}{$P$} & $\mathbf{P}$ & 2.000 \\
\hline $\mathrm{FeO}$ & 18.02 & 0.23 & & & \\
\hline $\mathrm{MnO}$ & 31.05 & 0.31 & \multirow[t]{5}{*}{$M(1)$} & $\mathrm{Fe}^{2+}$ & 1.000 \\
\hline $\mathrm{CaO}$ & 0.11 & 0.04 & & & \\
\hline $\mathrm{MgO}$ & 0.65 & 0.12 & & $\mathrm{Mn}$ & 1.798 \\
\hline $\mathrm{ZnO}$ & 0.17 & 0.07 & & $\mathrm{Fe}^{2+}$ & 0.030 \\
\hline $\mathrm{SrO}$ & 0.06 & 0.09 & & $\mathrm{Mg}$ & 0.066 \\
\hline $\mathrm{H}_{2} \mathrm{O}^{*}$ & 13.16 & & \multirow{5}{*}{$M(2)$} & $\mathrm{Ca}$ & 0.008 \\
\hline \multirow[t]{4}{*}{ Total } & 97.78 & & & $\mathrm{Zn}$ & 0.009 \\
\hline & & & & $\mathrm{Sr}$ & 0.002 \\
\hline & & & & sum & 1.947 \\
\hline & & & & $\mathrm{H}$ & 6.000 \\
\hline
\end{tabular}


Single-crystal diffraction data were collected using a Bruker Apex II diffractometer with MoK $\alpha$ radiation $(\lambda=0.71073 \AA)$. Some 7988 intensities were measured up to $2 \theta=31.34^{\circ}$, of which 1329 were unique $\left(\mathrm{R}_{\text {int }}=0.0309\right)$ giving a metrically orthorhombic unit-cell with: $a=9.4872(19), b=10.121(2), \mathrm{c}=8.7023(17)(\AA), V$ 835.6(3) $\left(\AA^{3}\right)$ and $\mathrm{Z}=4$ (Table 2).

A SADABS absorption correction was applied (Sheldrick, 2000) $\left(\mu=5.004 \mathrm{~mm}^{-1}\right)$. On the basis of systematic absences, the space group Pbna (no. 60) was selected unambiguously, in

Table 2: Single-crystal diffraction data and refinement parameters for correianevesite.

\begin{tabular}{|c|c|}
\hline \multicolumn{2}{|l|}{ Crystal data } \\
\hline Chemical formula & $\mathrm{Fe}^{2+} \mathrm{Mn}^{2+}{ }_{2}\left(\mathrm{PO}_{4}\right)_{2} * 3 \mathrm{H}_{2} \mathrm{O}$ \\
\hline $\mathrm{a}(\AA)$ & $9.487(2)$ \\
\hline $\mathrm{b}(\AA)$ & $10.121(2)$ \\
\hline c $(\AA)$ & $8.702(2)$ \\
\hline $\mathrm{V}\left(\AA^{3}\right)$ & $835.6(3)$ \\
\hline Z & 4 \\
\hline \multicolumn{2}{|l|}{ Data Collection } \\
\hline Instrument & APEX II CCD diffractometer \\
\hline Absorption correction & Empirical (SADABS, Sheldrick 2008) \\
\hline Radiation, wavelength $(\AA)$ & $\operatorname{MoK} \alpha, 0.71073$ \\
\hline $\mathrm{m}\left(\mathrm{mm}^{-1}\right)$ & 5.004 \\
\hline Min. $\Theta\left(^{\circ}\right)$ & 3.18 \\
\hline Max. $\Theta\left({ }^{\circ}\right)$ & 31.34 \\
\hline Measured reflections & 7988 \\
\hline $\mathrm{R}_{\text {int }}$ & 0.0309 \\
\hline Independent reflections & 1329 \\
\hline Observed reflections $[I>2 s(I)]$ & 1199 \\
\hline \multicolumn{2}{|l|}{ Refinement } \\
\hline Parameters refined & 88 \\
\hline Final $R[I>2 s(I)]$ and wR2 (all data) & 0.0163 and 0.0378 \\
\hline GoF & 1.103 \\
\hline$\Delta \rho_{\max }, \Delta \rho_{\min }\left(\mathrm{e} \AA^{-3}\right)$ & $0.45,-0.49$ \\
\hline
\end{tabular}

agreement also with statistical tests on the distribution of the $E$ values $\left[\left|E^{2}-1\right|=0.979\right]$ and confirmed by satisfactory refinement. The structure was refined, starting from the known atom coordinates of the phosphoferrite group using the SHELXL-2017 program (Sheldrick, 2008) implemented in the WinGX suite (Farrugia, 1999) to a final $\mathrm{R}=1.6 \%$ for 1199 observed reflections $[\mathrm{I}>2 \sigma(\mathrm{I})]$ (Table 2). Tables 3 shows the atom coordinates and equivalent isotropic parameters for correianevesite. In Table 4 are reported the anisotropic displacement parameters for correianevesite. 


\section{Analytical results}

The electron microprobe analyses show a strong homogeneity of the investigated specimen as evidenced by the very low standard deviation values ( $S D$ column in Table 1).

The empirical formula found, using the averaged chemical analysis normalized on the basis of $2 \mathrm{P}$ atoms per formula unit, is: $\mathrm{Fe}^{2+}\left(\mathrm{Mn}_{1.80} \mathrm{Mg}_{0.07} \mathrm{Fe}^{2+}{ }_{0.03} \mathrm{Ca}_{0.01}\right)_{\Sigma 1.91}\left(\mathrm{PO}_{4}\right)_{2} \cdot 3 \mathrm{H}_{2} \mathrm{O}$. It is in good agreement with the general formula of correianevesite. Compared to the composition described in Chukanov et al., (2014) Mn content is closer to 2 apfu and only minor $\mathrm{Mg}$ and $\mathrm{Ca}$ are present.

Table 3: Atom coordinates and equivalent displacement parameters $\left(\AA^{2}\right)$ for correianevesite.

\begin{tabular}{lcccccc}
\hline Atom & Element & Occupancy & $\mathrm{x} / \mathrm{a}$ & $\mathrm{y} / \mathrm{b}$ & $\mathrm{z} / \mathrm{c}$ & $\mathrm{U}_{\mathrm{eq}}$ \\
\hline \hline $\mathrm{M}(1)$ & $\mathrm{Fe} / \mathrm{Mg}$ & $0.923(3) / 0.077(3)$ & 0 & 0 & 0 & $0.00899(9)$ \\
$\mathrm{M}(2)$ & $\mathrm{Mn}$ & $1.000(2)$ & $0.06551(2)$ & $0.09704(2)$ & $0.63640(2)$ & $0.01004(6)$ \\
$\mathrm{P}$ & $\mathrm{P}$ & 1 & $0.20494(4)$ & $0.10607(3)$ & $0.29220(4)$ & $0.00713(8)$ \\
$\mathrm{O}(1)$ & $\mathrm{O}$ & 1 & $0.21665(11)$ & $0.25355(9)$ & $0.33318(12)$ & $0.0119(2)$ \\
$\mathrm{O}(2)$ & $\mathrm{O}$ & 1 & $0.10440(11)$ & $0.03796(10)$ & $0.40577(11)$ & $0.01117(19)$ \\
$\mathrm{O}(3)$ & $\mathrm{O}$ & 1 & $0.35171(10)$ & $0.04275(10)$ & $0.30099(12)$ & $0.0124(2)$ \\
$\mathrm{O}(4)$ & $\mathrm{O}$ & 1 & $0.14920(12)$ & $0.09673(10)$ & $0.12695(11)$ & $0.0145(2)$ \\
$\mathrm{OW} 1$ & $\mathrm{O}$ & 1 & $-0.0936(2)$ & 0.25 & 0.5 & $0.0205(3)$ \\
$\mathrm{OW} 2$ & $\mathrm{O}$ & 1 & $-0.02822(12)$ & $0.32674(10)$ & $0.14658(12)$ & $0.0117(2)$ \\
$\mathrm{H} 11$ & $\mathrm{H}$ & 1 & $-0.147(3)$ & $0.301(2)$ & $0.541(3)$ & $0.046(7)$ \\
$\mathrm{H} 21$ & $\mathrm{H}$ & 1 & $0.020(3)$ & $0.259(3)$ & $0.129(3)$ & $0.051(8)$ \\
$\mathrm{H} 22$ & $\mathrm{H}$ & 1 & $-0.128(3)$ & $0.294(2)$ & $0.156(3)$ & $0.053(8)$ \\
\hline
\end{tabular}

Table 4: Anisotropic displacement parameters $\left(\AA^{2}\right)$ for correianevesite.

\begin{tabular}{lcccccc}
\hline & $U_{11}$ & $U_{22}$ & $U_{33}$ & $U_{23}$ & $U_{13}$ & $U_{12}$ \\
\hline \hline $\mathrm{M}(1)$ & $0.01041(15)$ & $0.00779(14)$ & $0.00875(14)$ & $-0.00009(10)$ & $0.00264(10)$ & $-0.00126(10)$ \\
$\mathrm{M}(2)$ & $0.01150(11)$ & $0.00948(10)$ & $0.00915(10)$ & $-0.00082(7)$ & $0.00012(7)$ & $-0.00296(8)$ \\
$\mathrm{P}$ & $0.00641(15)$ & $0.00726(15)$ & $0.00772(15)$ & $-0.00037(12)$ & $0.00050(12)$ & $-0.00031(12)$ \\
$\mathrm{O}(1)$ & $0.0121(5)$ & $0.0070(4)$ & $0.0168(5)$ & $-0.0016(4)$ & $0.0006(4)$ & $0.0000(4)$ \\
$\mathrm{O}(2)$ & $0.0108(5)$ & $0.0117(5)$ & $0.0110(4)$ & $0.0002(4)$ & $0.0020(4)$ & $-0.0038(4)$ \\
$\mathrm{O}(3)$ & $0.0089(5)$ & $0.0111(5)$ & $0.0172(5)$ & $-0.0012(4)$ & $0.0008(4)$ & $0.0026(4)$ \\
$\mathrm{O}(4)$ & $0.0164(5)$ & $0.0185(5)$ & $0.0085(4)$ & $-0.0001(4)$ & $-0.0016(4)$ & $-0.0045(4)$ \\
$\mathrm{OW} 1$ & $0.0212(8)$ & $0.0172(8)$ & $0.0229(8)$ & $-0.0043(7)$ & 0 & 0 \\
$\mathrm{OW} 2$ & $0.0117(5)$ & $0.0092(5)$ & $0.0141(5)$ & $-0.0009(4)$ & $-0.0002(4)$ & $-0.0008(4)$ \\
\hline
\end{tabular}

The crystal structure of correianevesite consists of sheets of corner- and edge-sharing octahedra parallel to $\{100\}$ (Fig. 2). The octahedral sheets are connected in the direction [100] by cornersharing tetrahedra as previously described by Moore et al. (1980) about phosphoferrite structure type. In particular, the octahedra sheet results to be formed by trimers $\mathrm{M}(2)-\mathrm{M}(1)-\mathrm{M}(2)$ connected via the OW2-O3 edge (Fig. 3). In the $b-c$ plain trimers are connected by O2-O2 edge 
sharing (Fig 3) as observed previously by Moore et al. (1980) for the structural formula $\mathrm{M}(1) \mathrm{M}(2)_{2}\left(\mathrm{PO}_{4}\right)_{2} \cdot 3 \mathrm{H}_{2} \mathrm{O}$ described in the introduction chapter. Figure 2 shows that both $\mathrm{H}_{2} \mathrm{O}$ molecules are contained in the octahedral sheets. In particular the oxygen OW2 forms the shared edge connecting, together with $\mathrm{O} 3$, the $\mathrm{M}(1)$ and $\mathrm{M}(2)$ polyhedra in the trimers. The oxygen OW1 connects the chains of $\mathrm{M}(2)-\mathrm{M}(1)-\mathrm{M}(2)$ trimers via edge sharing in the $b$-c plane Fig. 2). Figure 4 shows the structure of correianevesite along $a$. The octahedral sites $M(1)$ accommodates $\mathrm{Fe}^{2+}$, whereas the octahedral site $\mathrm{M}(2)$ hosts divalent cations constituted mainly by $\mathrm{Mn}$ and the remnant $\mathrm{Fe}$; minor $\mathrm{Ca}, \mathrm{Zn}$ and $\mathrm{Sr}$ are also present. The tetrahedral site is considered fully occupied by $\mathrm{P}$.

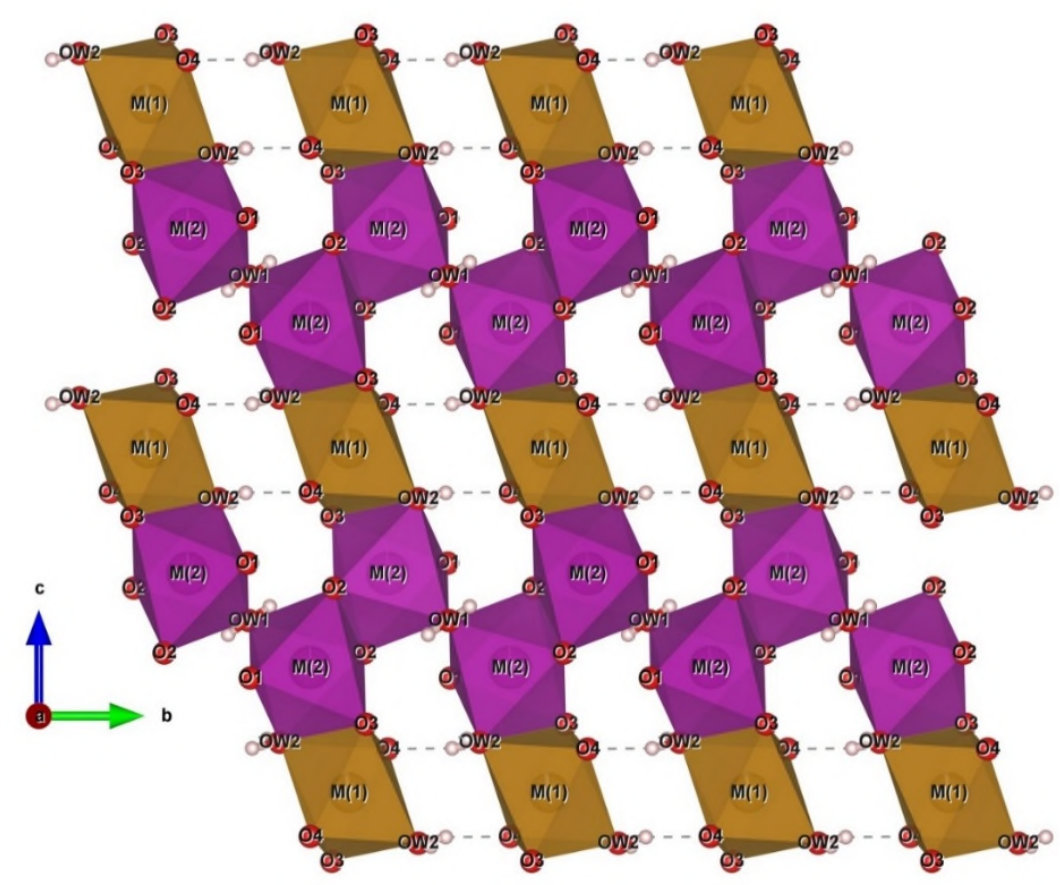

Figure 2: The octahedral sheet in the $b-c$ plane. (Drawn by VESTA, Momma and Izumi 2011).

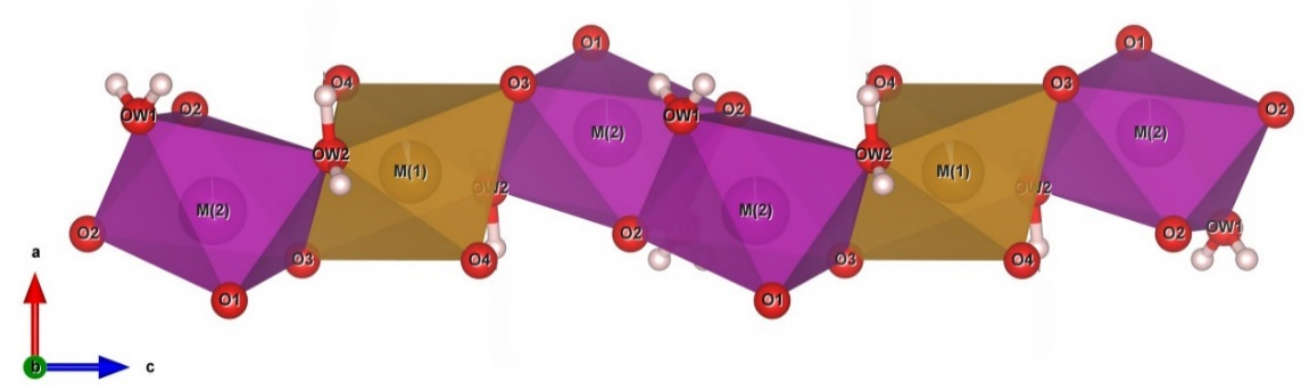

Figure 3: The $M(2)-M(1)-(M 2)$ trimers and their bonding in the chain. (Drawn by VESTA, Momma and Izumi 2011) 


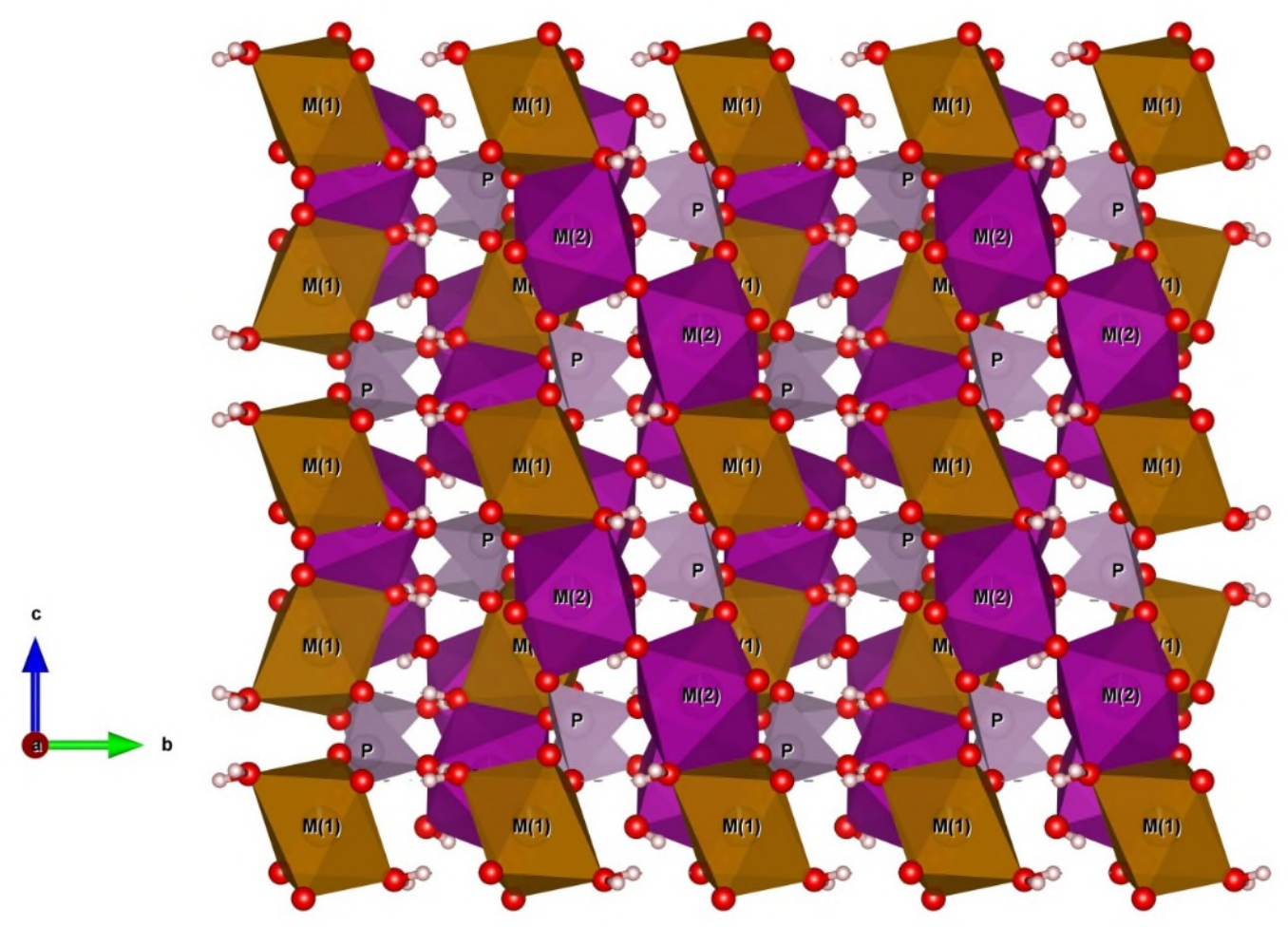

Fig. 4: The structure of correianevesite down to $a$ (Drawn by VESTA, Momma and Izumi 2011).

\section{Discussion and conclusions}

The chemical composition of the specimen of correianevesite studied in this work is closer to the theoretical formula of this species in respect to the composition shown by Chukanov et al. (2014) for the type specimen. The crystal structure of correianevesite refined in this work conforms closely to the structure described in Moore et al. (1980). In both structures the M(1) octahedra is populated mainly by $\mathrm{Fe}^{2+}$, and $\mathrm{M}(2)$ octahedra is populated by divalent cations mainly $\mathrm{Mn}$ and Fe. The tetrahedral site is occupied by $\mathrm{P}$. The average cation-oxygen distances of the coordination polyhedra described in this work (Table 5) and in Chukanov et al. (2014) are comparable, $\mathrm{M}(1)-\mathrm{O} 2.168$ and 2.170, M(2)-O 2.204 and 2.201, and P-O 1.573 and $1.538 \AA$ respectively. The distortion of the crystallographic sited in the crystal structure of correianevesite from the Emmons pegmatite and of the type specimen are comparable with values for $\mathrm{M}(1)$ of 0.0377 and 0.0395 respectively (calculated using VESTA, Momma and Izumi, 2011), for $\mathrm{M}(2)$ of 0.0429 and 0.0426 , and for the $\mathrm{P}$ of 0.0009 and 0.0008 . The electronic densities of sites $\mathrm{M}(1)$ and $\mathrm{M}(2)$ calculated from crystal structure and from the empirical formula are comparable. 
Table 5: Selected bond distances $(\AA)$ for correianevesite

\begin{tabular}{lclc}
\hline $\mathrm{M}(1)-\mathrm{O}(4)(\mathrm{x} 2)$ & $2.045(1)$ & $\mathrm{P}-\mathrm{O}(3)$ & $1.535(1)$ \\
$\mathrm{M}(1)-\mathrm{OW} 2(\mathrm{x} 2)$ & $2.185(1)$ & $\mathrm{P}-\mathrm{O}(4)$ & $1.535(1)$ \\
$\mathrm{M}(1)-\mathrm{O}(3)(\mathrm{x} 2)$ & $2.273(1)$ & $\mathrm{P}-\mathrm{O}(2)$ & $1.537(1)$ \\
average $\mathrm{M}(1)-\mathrm{O}$ & 2,168 & $\mathrm{P}-\mathrm{O}(1)$ & $1.539(1)$ \\
distortion index* & 0.03767 & average P-O & 1.537 \\
& & distortion index* & 0.00088 \\
$\mathrm{M}(2)-\mathrm{O}(1)$ & $2.101(1)$ & & \\
$\mathrm{M}(2)-\mathrm{O}(2)$ & $2.126(1)$ & $\mathrm{OW} 1-\mathrm{H}(11)(\mathrm{x} 2)$ & $0.80(2)$ \\
$\mathrm{M}(2)-\mathrm{O}(2)$ & & \\
$\mathrm{M}(2)-\mathrm{O}(3)$ & $2.145(1)$ & $\mathrm{OW} 2-\mathrm{H}(21)$ & $1.00(3)$ \\
$\mathrm{M}(2)-\mathrm{OW} 1$ & $2.161(1)$ & $\mathrm{OW} 2-\mathrm{H}(22)$ & \\
$\mathrm{M}(2)-\mathrm{OW} 2$ & $2.467(1)$ & \\
average M(2)-O & $2.225(1)$ & & \\
distortion index* & 2,204 & \\
\hline * calculated using VALENCE (Momma and Izumi 2011) &
\end{tabular}

The values are respectively 24.82 and 24.22 for site $\mathrm{M}(1)$ and 24.46 and 24.23 for site $\mathrm{M}(2)$. Table 6 shows the hydrogen-bonding geometry in correianevesite from the Emmons pegmatite. Table 7 provides electrostatic valence balance calculations $(\Sigma)$ of cations about anions calculated following Brown (1996) using the parameters of Gagné and Hawthorne (2015). In particular the total bond-valence sum of site $\mathrm{M}(1)$ is 1.92 allowing the presence of divalent cations only. The bond-valence sum of $\mathrm{M}(2)$ site is 2.053 valence units confirming the presence of divalent cations. The site $\mathrm{P}$ shows a bond-valence sum of 4.981 valence units confirming to be populated only by $\mathrm{P}^{5+}$.

Table 6: Bond distances $(\AA)$ and angles $\left(^{\circ}\right)$ for the hydrogen bonding in correianevesite

\begin{tabular}{|c|c|c|c|c|c|c|}
\hline donor & & acceptor & D-H & H...A & D-A & D-H...A \\
\hline \multirow[t]{5}{*}{ OW1 } & H11 & $\mathrm{O}(1)$ & $0.81(3)$ & 2.91(3) & $3.413(2)$ & $123(2)$ \\
\hline & & $\mathrm{O}(2)$ & & $2.92(3)$ & $2.968(2)$ & $85(2)$ \\
\hline & & $\mathrm{O}(2)$ & & $2.70(2)$ & $3.029(1)$ & $107(2)$ \\
\hline & & $\mathrm{O}(3)$ & & $2.76(2)$ & $3.395(1)$ & $137(2)$ \\
\hline & & $\mathrm{O}(4)$ & & $2.32(2)$ & $3.095(2)$ & $162(2)$ \\
\hline \multirow[t]{5}{*}{ OW2 } & $\mathrm{H} 21$ & $\mathrm{O}(1)$ & $0.84(3)$ & $2.57(3)$ & $2.930(2)$ & $107(2)$ \\
\hline & & $\mathrm{O}(4)$ & & $2.04(3)$ & $2.787(2)$ & $170(3)$ \\
\hline & & $\mathrm{O}(3)$ & & $2.77(3)$ & $3.125(1)$ & $107(2)$ \\
\hline & & $\mathrm{O}(4)$ & & 2.93(3) & $3.016(1)$ & $87(2)$ \\
\hline & & OW2 & & $2.59(3)$ & $2.987(1)$ & $110(2)$ \\
\hline \multirow[t]{2}{*}{ OW2 } & $\mathrm{H} 22$ & $\mathrm{O}(1)$ & $1.00(3)$ & $1.54(3)$ & $2.537(2)$ & $176(3)$ \\
\hline & & $\mathrm{O}(3)$ & & $2.58(2)$ & $3.125(1)$ & $114(2)$ \\
\hline
\end{tabular}


Bulletin de la Société Royale des Sciences de Liège, Vol. 90, articles, 2021, p. 125 - 135

Table 7: Bond-valence calculation for correianevesite

\begin{tabular}{cccc}
\hline & $\mathrm{M}(1)$ & $\mathrm{M}(2)$ & $\mathrm{P}$ \\
\hline \hline O1 & & 0.431 & 1.237 \\
$\mathrm{O} 2$ & 0.403 & 1.244 \\
O2' & & 0.383 & \\
O3 & $0.233 \times 2$ & 0.367 & 1.25 \\
O4 & $0.431 \times 2$ & & 1.25 \\
OW1 & & 0.160 & \\
OW2 & $0.296 \times 2$ & 0.309 & \\
sum & $\mathbf{1 . 9 2 0}$ & $\mathbf{2 . 0 5 3}$ & $\mathbf{4 . 9 8 1}$ \\
\hline
\end{tabular}

\section{References}

Brown I.D., 1996. Valence: a program for calculating bond valences. Journal of Applied Crystallography, 29, 479-480.

Černý P. and Ercit T.S. 2005. The Classification of Granitic Pegmatites Revisited. Canadian Mineralogist, 43, 2005-2026.

Chukanov N.V., Scholz R., Zubkova N.V., Pekov I.V., Belakovskiy D.I., Van K.V., Lagoeiro L., Graca L.M., Krambrock K., de Oliveira L.C.A., Menezes Filho L.A.D., Chaves M.L.S.C., and Pushcharovsky D.Y., 2014. Correianevesite, $\mathrm{Fe}^{2+} \mathrm{Mn}^{2+}{ }_{2}\left(\mathrm{PO}_{4}\right)_{2} \cdot 3 \mathrm{H}_{2} \mathrm{O}$, a new reddingitegroup mineral from the Cigana mine, Conselheiro Pena, Minas Gerais, Brazil. American Mineralogist, 99, 811-816.

Falster A.U., Simmons W.B., Webber K.L., Dallaire D.A., Nizamoff J.W., Sprague R.A 2019. The Emmons pegmatite, Greenwood, Oxford County, Maine. Rocks et Minerals, 94, 498-519.

Fransolet A-M, 1975. Étude minéralogique et pétrologique des phosphates de pegmatites granitiques. PhD thesis, University of Liège, $333 \mathrm{p}$.

Gagné O.C. and Hawthorne F.C., 2015. Comprehensive derivation of bond-valence parameters for ion pairs involving oxygen. Acta Crystallographica, B71, 562-578.

Hanson S.L., Falster A.U., Simmons W.B., Sprague R., Vignola P., Rotiroti N., Andò S. and Hatert F., 2018. Tantalowodginite, $(\mathrm{Mn} 0.5 \square 0.5) \mathrm{TaTa}_{2} \mathrm{O}_{8}$, a new mineral species from the Emmons pegmatite, Uncle Tom Mountain, Maine, U.S.A. Canadian Mineralogist, 56, 543553.

King V. and Foord E., 1994. Mineralogy of Maine - Volume 1: Descriptive mineralogy: Maine Geological Survey, 418 p.

Momma K. and Izumi F., 2011. VESTA 3 for three-dimensional visualization of crystal, volumetric and morphology data. Journal of Applied Crystallography, 44, 1272-1276. 
Bulletin de la Société Royale des Sciences de Liège, Vol. 90, articles, 2021, p. 125 - 135

Moore P.B., 1973. Pegmatite phosphates: descriptive mineralogy and crystal chemistry. Mineralogical Record, 4, 103-130.

Moore P.B., Araki T. and Kampf A.R., 1980. Nomenclature of the phosphoferrite structure type: refinements of landesite and kryzhanovskite. Mineralogical Magazine, 43, 789-795.

Sheldrick G.M., 2000. SADABS Area-Detector Absorption Correction Program, Bruker AXS Inc., Madison, WI, USA.

Sheldrick G.M., 2008. A short history of SHELX. Acta Crystallographica, A64, 112-122.

Simmons W.B., Webber K.L., Falster A.U. and Nizamoff J.W., 2003. Pegmatology:

pegmatite mineralogy, petrology and petrogenesis. Rubellite Press, New Orleans 176 pages. 